\title{
Hemşirelik Fakültesi Birinci ve Dördüncü Sınıf Öğrencilerinin Mezuniyet Sonrası Kariyer Planlarının İncelenmesi
}

\author{
Examining Post Graduation Career Plans of First and Fourth Grade Students in a \\ Nursing Faculty
}

\author{
Seda ÇAĞLAR', Duygu GÖZEN² ${ }^{2}$, Gizem KERIMOĞLU YILDIZ ${ }^{3}$, Nurdan KILIKLI ${ }^{4}$, Mustafa AĞAR $^{5}$
}

İletişim/ Correspondence: Gizem KERIMOĞLU YILDIZ Adres/ Address: İstanbul Üniversitesi Florence Nightingale Hemşirelik Fakültesi, Çocuk Sağlığı ve Hastalıkları Hemşireliği AD., Abide-i Hürriyet Cad. 34381, Şişli/ İstanbul Tel: 021244000 00/ 27072 Fax: 02122244990 E-mail: gizemkrm@gmail.com

\begin{abstract}
$\ddot{O} Z$
Amaç: Araştırma, İstanbul'daki bir üniversitenin hemşirelik fakültesinde öğrenim gören birinci ve dördüncü sinıftaki hemşirelik öğrencilerinin mezuniyet sonrası kariyer planlarını incelemek amaclyla gerçekleștirildi.

Yöntem: Tanımlayıcı tipte planlanan araștırmanın evrenini İstanbul'daki bir üniversitenin hemşirelik bölümünde yükseköğrenime devam eden öğrenciler; örneklemini ise araștırmaya katılmaya gönüllü olan, sosyo-demografik özellikleri ve kariyer planlarına yönelik 14 maddelik anket formunu eksiksiz dolduran, 1 . $(n=109)$ ve 4. (n=108) sinıflarda ögrenim gören toplam 217 ögrenci oluşturdu. Verilerin değerlendirmesinde ortalama, yüzdelik ve ki-kare testleri kullanıldl. Bulgular: Öğrencilerin yaş ortalamasının $20.02 \pm 3.26$ yll olduğu, \%50.2 sinin 1.sinıfta, \%49.8'inin 4. sinıfta ögrrenim gördüğ̈̈, büyük çoğunluğunun (\%37.3) ailesinin Marmara Bölgesi’nde yaşadı̆̆, 1.sinı öğrencilerinin \%57'sinin, 4. sinıf ögrencilerinin \%43'ünün okula bilinçli geldiği, 1. sinıf öğrencilerin \%54.7 sinin; 4. sinıf ögrencilerin \% 45.3 'ünün hemşirelikte ilerlemek ve lisansüstü eğitim almak istediği belirlendi. Birinci stnıf öğrencilerinin \%53.3 'ünün, 4. sinıf ögrencilerinin ise \%46.7 sinin mezuniyet sonrası İstanbul'da yaşamak istediği belirlendi. Koruyucu sağllk hizmetlerinde çallşmak isteyen öğrencilerin \%83.3 'ünün ve eğitimci olmak isteyenlerin ise \%88.2 'sinin dördüncü sinıf olduğu belirlendi. Bu bulguların da istatistiksel olarak anlamlı düzeyde farkla dördüncü sinıf ögrencilerinin lehine olduğu belirlendi $(p<0.05)$.

Sonuç: Birinci sınıf ögrencilerin dördüncü sınıf ögrencilere göre daha bilinçli bir şekilde hemşirelik mesleğini tercih ettikleri, öğrencilerin çoğunluğunun ileriye yönelik sadece hemşirelik eğitimlerini bitirmeyi planladıkları ve aynı zamanda öğrenimlerini tamamladıklarında hemşirelikte ilerlemek ve yüksek lisans yapmayı planladıkları, özellikle 4. sını öğrencilerinin koruyucu sağlık hizmetlerinde çalışmak istedikleri, çoğunluğunun eğitimlerini tamamladiktan sonra kariyerlerine İstanbul'da devam etmek istedikleri ve bunun primer nedenlerinin de İstanbul'da çalı̧̧ma olanaklarinın ve sosyal olanakların daha fazla olması olarak belirlenmiştir

Anahtar Kelimeler: Üniversite ögrencisi, hemşire, kariyer planlama.
\end{abstract}

\begin{abstract}
Aim: Study was performed at a nursing department of an university in İstanbul to determine first and forth grade nursing students' career plans after graduation.

Method: Population of the study consisted of nursing students who were continuing their education at Nursing department of an University in Istanbul. Sample of study included 217 first $(n=109)$ and fourth $(n=108)$ grade nursing students who voluntarily attended and completed the survey which has 14 questions about sociodemographic status and occupational future plans. We used mean, percentil and chi-square tests for analysis.

Results: It was found that mean age of students $20.02 \pm 3.26$ year, $50.2 \%$ of them at first grade, $49.8 \%$ of them at forth grade and $37.3 \%$ of their parents live in the Marmara Region. 57\% of first grade students and $43 \%$ of forth grade students have chosen nursing profession in a concious way and $54.7 \%$ of first grade students and $45.3 \%$ of the forth grade students want to advance in nursing and attend to a master program in nursing. It is determined $53.3 \%$ of first grade and $46.7 \%$ of fourth grade students want to live in Istanbul in the future. It was found $83.3 \%$ of the students who want to work at preventive health care services and $88.2 \%$ of who want to be an instructor were forth grade nursing students. These results have statistically significant difference for forth grade students ( $p<0.05$ ). Conclusion: It has been determined that first grade students has chosen nursing profession more concious than fourth grade students, most of the students planing to finish only nursing education for the future and at the same time when they finished nursing education program they were planning to advance in nursing profession and continue to a master program in nursing. Especially forth grade students stated that they would like to work at preventive health services. Most of the students want to live in Istanbul and they want to contuniue their carrier in Istanbul and the primary reasons of this are having too many job and social opportunities in İstanbul.
\end{abstract}

Keywords: University student, nurse, career planning.

10. Uluslararası Katılımlı Ulusal Hemşirelik Öğrencileri Kongresi’nde poster bildiri olarak sunulmuştur (28-30 Nisan 2011, Gaziantep/ TÜRKIYY) ${ }^{l} Y r d$. Doç. Dr. İstanbul Üniversitesi Florence Nightingale Hemşirelik Fakültesi, İstanbul/ TURKEY, ${ }^{2}$ Doç. Dr. İstanbul Üniversitesi Florence Nightingale Hemşirelik Fakültesi, İstanbul/ TURKEY, ${ }^{3}$ Arş. Gör. İstanbul Üniversitesi Florence Nightingale Hemşirelik Fakültesi, İstanbul/ TURKEY, ${ }^{4}$ Hemşire, Koşuyolu Yüksek İhtisas Eğitim ve Araştırma Hastanesi, Istanbul/ TURKEY, ${ }^{5}$ Hemşire, Acıbadem Atakent Hastanesi, İstanbul/ TURKEY

Yazının gönderilme tarihi: 11.04.2016

Yazının basım için kabul tarihi: 12.12.2016

doi: $10.17672 /$ fnhd.97895 


\section{GİRIŞ}

Kariyer, yaşam boyu devam eden ve kişinin bir iş alanında ilerlemek, maddi olarak güçlenmek, daha fazla sorumluluk ve statü sahibi olmak, güç ve saygınlık kazanabilmek için yaptığı girişimler sonucu şekillenir. Kişinin başarı derecesini, yükselmesini ve bunların yanında bireyin kendini gerçekleştirme, iş doyumu gibi psikolojik ve sosyolojik süreçleri de yansıtır (Dikili 2012). Kariyer planlama ise; bireyin sahip olduğu bilgi, yetenek, beceri ve güdülerini geliştirerek, içinde bulunduğu yapı içinde ilerleyişini planlamasıdır (Göz ve Gürbüz 2008). Planlama süreci ve kariyer geliştirme bireyin devam eden profesyonel gelişiminin parçasıdır (Donner ve Wheeler 2001). Bu sürecin sağliklı gelişmesi, bireyin iş ortamındaki üretkenliğini arttırmanın yanı sıra iş doyumunu da olumlu etkiler (Göz ve Gürbüz 2008).

Hemşireler açısından kariyer planlaması ele alındığında; çalışma alanını kendi istekleri doğrultusunda tercih eden hemşireler, çalışmalarını daha sağlıklı ve üretken biçimde gerçekleştirerek toplum sağlığının gelişmesine daha aktif katkı sağlayacaklardır (Göz ve Gürbüz 2008). Kariyer planlama zaman içerisinde hemşirenin becerilerinin, deneyimlerinin bir parçası haline gelerek profesyonel gelişim ve hedeflerine ulaşımını sağlar. Hemşireler kariyer planlama için gereken benzer becerileri çalışma alanında, hasta bakımında problem çözme ve hemşirelik süreci aşamalarında kullanmaktadırlar (Donner ve Wheeler 2001).

Uluslararası Hemşireler Konseyi (International Council of Nurses- ICN) hemşirelik alanında kariyer planlamanın önemini 1995 y1lında "Hemşireler İçin Kariyer Geliştirme" adını verdikleri bir belge ile bildirmiştir. $\mathrm{Bu}$ belgede hemşirelikte kariyer geliştirmenin hem çalışma alanlarında hem de eğitim sisteminde, yönetici-profesyonellerin tutum ve uygulamalarıyla desteklenmesinin önemi vurgulanmıştır. ICN aynı zamanda kariyer planlamanın meslekte doyum ve kendini değerli hissetme duygularını geliştirdiğini ifade etmektedir (ICN 1995).

ICN'in de belirttiği gibi hemşirelikte kariyer planlamada eğitimciler ve okullar önemli rol oynamaktadır.
Eğitimciler, eğitim süresi boyunca öğrencilerin bakış açılarını geliştirmelerine yardımcı olarak kendilerini tanımaları ve kariyer firsatlarını keşfetmelerini sağlarlar (Donner ve Wheeler 2001; Göz ve Gürbüz 2008). Hemşirelik okulları, öğrencilerin eğitimlerine yardımcı olmanın yanında kariyerlerini, hedeflerini belirleme, kariyer planlama sürecini öğrenme ve kullanmalarına yardımcı olmaktadır. Kariyer planlama hemşire öğrencilerin öğrenim yaşamlarının bir parças1 haline gelmekte, yeniliklere açık ve değişime karşı durmak yerine değişim yaratan bireyler olabilmektedirler (Donner ve Wheeler 2001). Hemşirelikte lisans programları; öğrencilerin bireysel olarak profesyonel süreçte sosyalleşmelerine, isteklerini ve ilgilerini karşılamak için daha ileri eğitim imkanlarına açık hale gelmelerine olanak sağlamaktadır (Rognstad, Aasland ve Granum 2004).

Öğrenciler için üniversitedeki son yıl, gelecekle ilgili kariyer planı yapılan yıldır. Mezuniyetten sonra hemşire öğrencilerden ilgilerine ve ihtiyaçlarına uygun çalışma alanları seçmeleri beklenir (Andrew 2013; McKenna, McCall ve Wray 2010; Yıldırım, Keçeci ve Bulduk 2011). Bu dönemde öğrenciler genellikle tercihleri konusunda emin olamamakla birlikte bazıları gelecek kariyerleri konusunda daha kararlıdır. Bazı öğrenciler eğitimlerini geliştirmek isteyebilir (Rognstad 2002), bazıları ise klinik deneyim kazanmak adına bir süre klinikte çalışmayı düşünebilir. Günümüzde hemşirelikte ileri eğitim ve uzmanlaşma için birçok seçenek vardır (Edwards, Smith, Courtney, Finlayson ve Chapman 2004; Henderson, Cooke, Creedy ve Walker 2012; Rognstad, ve ark. 2004). Öğrenciler genellikle eğitim gördükleri kurumda çalışmayı da tercih edebilmektedir (Lai ve ark. 2008). Yapılan bir çalışmada, öğrencilerin hangi klinik alanda ya da hangi coğrafik bölgede çalışacaklarının eğitim aldıkları kurum ile oldukça ilgili olduğu belirtilmiştir (McKenna ve ark. 2010). Bu nedenle öğrencilerin son deneyim yaşadıkları okul, onların gelecekteki çalışma planlarını ve tercihlerini yönlendirebilmektedir (Morrel ve Ridgway 2014). Maaş, iş yükü, hastanenin bulunduğu coğrafik bölge, 
hastanenin büyüklüğü gibi birçok faktör de öğrencilerin kariyer planlarını etkileyebilmektedir (Fenush ve Hupcey 2008; Neilson ve McNally 2010; Shih ve Chuang 2008). Tüm bunlara ek olarak çalışma yerinin belirlenmesinde, küreselleşme dinamiği, eğitim düzeyinin yükseltilmesi ve teknolojik ilerlemeler bireylerin bilinçlenmesini sağlayarak, beklentilerinde de artışa neden olmuştur. Artan beklentiler, hemşireleri daha iyi eğitim almak, daha iyi ortamda (teknolojik ve yönetsel anlamda) çalışmak, hasta ilişkileri konusunda daha donanımlı olmak konusunda zorlamaktadır (Y1ldırım 2009).

Gelişmekte olan ülkelerde son sınıftaki hemşirelik öğrencilerinin gelecekteki çalışma hayatını planlamalarına ve kariyer tercihlerine yönelik az sayıda araştırma vardır (Shoqirat ve Abu-Qamar 2015). Türkiye'de bu konu ile ilgili yapılmış çok az çalışmaya rastlanmıştır (Çıtak-Tunç, Akansel ve Özdemir 2010). Bu bağlamda çalışma, İstanbul'daki bir üniversitenin hemşirelik fakültesinde öğrenim gören 1. ve 4. sınıftaki hemşirelik öğrencilerinin mezuniyet sonrası kariyer planlarını incelemek amacıyla gerçekleştirildi.

\section{YÖNTEM}

\section{Araştırmanın Tipi}

Araştırma, tanımlayıcı olarak yapıldı.

Araştırma soruları;

1. Birinci ve dördüncü sınıf hemşirelik bölümünde öğrenim gören öğrencilerin hemşirelik bölümünü tercih etme sıraları ve nedenleri arasında fark var midır?

2. Birinci ve dördüncü sınıf hemşirelik öğrencilerinin mezuniyet sonrası kariyer planları arasında fark var midir?

3. Birinci ve dördüncü sınıf hemşirelik öğrencilerinin mezuniyet sonrası İstanbul'u tercih etme nedenleri nelerdir?

\section{Araştırma Evreni ve Örneklemi}

Araştırmanın evrenini İstanbul ilindeki bir üniversitenin hemşirelik bölümünde yükseköğrenime birinci ve dördüncü sınıfta öğrenimine devam eden öğrenciler $(\mathrm{N}=318)$, örneklemini ise araştırmaya katılmaya gönüllü olan ve anketi eksiksiz dolduran, birinci $(n=109)$ ve dördüncü ( $n=108)$ sinıflarda öğrenim gören toplam 217 öğrenci oluşturdu.

\section{Veri Toplama Araçları ve Verilerin Toplanması}

Araştırmanın verileri, yazarlar tarafından oluşturulan, öğrencilerin sosyo-demografik özellikleri (yaş, cinsiyet, uyruk, okula başlangıç yılı, öğrenim gördüğü s1nıf, ailesinin yaşadığı bölge) ile İstanbul'daki yaşam ve mesleki geleceklerine yönelik (İstanbul'da yaşad1ğ1 yer ve süresi, bölümü tercih etme nedeni, öğrenim görmek istediği başka bir bölüm varlığı, öğrenimi sona erdiğinde planladığ 1 kariyer hedefi ve yaşamay1 planladığ 1 şehir) toplam 14 sorudan oluşan anket formu ile toplandı. Anket formları, öğrencilerin ders döneminde 2 haftalık süre içinde, ders sonlarında birebir uyguland.

\section{Araştırmanın Etik Yönü}

Çalışmanın yapılabilmesi için fakülteden gerekli kurum izni alındı. Çalışmaya katılımda gönüllülük ilkesine dikkat edilerek çalışma öncesinde öğrenciler çaış̧manın amacı ile ilgili olarak bilgilendirilerek, onam formu alındi.

\section{Verilerin Değerlendirilmesi}

Elde edilen verilerin analizinde SPSS 20 programında ortalama, yüzdelik ve ki-kare testi kullanıldı.

\section{Araştırmanın Sınırlııkları}

Araştırmanın bulguları, bir üniversitenin hemşirelik bölümünde yapılması nedeniyle tüm hemşirelik öğrencilerine genellenemez.

\section{BULGULAR}

Araştırma kapsamındaki öğrencilerin yaş ortalamasının $20.02 \pm 3.26$ y1l olduğu, \%50.2'sinin 1. sınıfta, $\% 49.8$ 'inin 4. sinıfta öğrenim gördüğü, \%88.5'inin k1z olduğu ve büyük çoğunluğunun (\%37.3) ailesinin Marmara Bölgesi'nde yaşadığı belirlendi (Tablo 1). 
Tablo 1. Öğrencilere İlişkin Demografik Veriler $(\mathrm{N}=217)$

\begin{tabular}{|l|c|c|}
\hline Özellikler & n & \% \\
\hline Sinıf & 109 & 50.2 \\
\hline 1. sınıf & 108 & 49.8 \\
4. sınıf & \multicolumn{2}{|}{} \\
\hline Cinsiyet & 192 & 88.5 \\
\hline Kız & 25 & 11.5 \\
Erkek & \multicolumn{2}{|}{} \\
\hline Ailenin yaşadı̆̆ı bölge & 81 & 37.3 \\
\hline Marmara & 15 & 6.9 \\
Ege & 33 & 15.2 \\
Akdeniz & 49 & 22.6 \\
Karadeniz & 8 & 3.7 \\
Doğu Anadolu & 19 & 8.8 \\
İç Anadolu & 12 & 5.5 \\
Güneydoğu Anadolu & \multicolumn{2}{|l|}{} \\
\hline
\end{tabular}

Öğrencilere "Hemşirelik bölümünü tercih sıraları ve tercih etme nedenleri” sorulduğunda; birinci sınıf öğrencilerinin \%57'sinin, dördüncü sınıf öğrencilerinin \%43'ünün "okula isteyerek ve bilinçli geldim" cevabını verdikleri ve 1. sinıfların lehine aralarında istatistiksel olarak anlamlı derecede farklılık olduğu saptandı $(\mathrm{p}<0.05)$. Birinci sınıf öğrencilerin lisans eğitiminde hemşireliği tercih

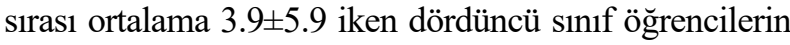
$2.1 \pm 4.2$ olduğu belirlendi ve bu fark istatistiksel olarak anlamlı bulundu ( $\mathrm{F}=12.982 ; \mathrm{p}=0.012 *)$ (Tablo 2).

Tablo 2. Öğrencilerin Hemşirelik Bölümünü Tercih Etme Nedenleri ve Tercih Siraları $(\mathrm{N}=217)$

\begin{tabular}{|c|c|c|c|c|c|}
\hline \multirow{2}{*}{$\begin{array}{l}\text { Hemşireliği } \\
\text { tercih etme } \\
\text { nedenleri } \\
\text { İsteyerek ve } \\
\text { bilinçli geldim }\end{array}$} & \multicolumn{2}{|c|}{$\begin{array}{l}\text { 1.sınıf } \\
\text { n } \%\end{array}$} & \multicolumn{2}{|c|}{$\begin{array}{l}\text { 4.sinıf } \\
n \%\end{array}$} & \multirow{2}{*}{$\begin{array}{c}\mathbf{X}^{2} ; \mathbf{p} \\
3.880 ; 0.049^{*}\end{array}$} \\
\hline & 61 & 57 & 46 & 43 & \\
\hline $\begin{array}{l}\text { Ailem istediği için } \\
\text { geldim }\end{array}$ & 8 & 38.1 & 13 & 61.9 & $1.321 ; 0.250$ \\
\hline $\begin{array}{l}\text { Puanım buna } \\
\text { yettiği için geldim }\end{array}$ & 9 & 31 & 20 & 69 & $4.834 ; 0.280$ \\
\hline $\begin{array}{l}\text { İş imkanı bula- } \\
\text { bileceğim için } \\
\text { geldim }\end{array}$ & 32 & 43.8 & 41 & 56.2 & $1.692 ; 0.193$ \\
\hline $\begin{array}{l}\text { Maddi beklentile- } \\
\text { rimi karşılayacağı } \\
\text { için geldim }\end{array}$ & 2 & 25 & 6 & 75 & $3.123 ; 0.210$ \\
\hline $\begin{array}{l}\text { Hemşireliği } \\
\text { tercih etme sırası }\end{array}$ & \multicolumn{2}{|c|}{$\begin{array}{l}\text { 1. sinıf } \\
(n=109)\end{array}$} & \multicolumn{2}{|c|}{$\begin{array}{l}\text { 4. } \sin I f \\
(n=108)\end{array}$} & $F ; p$ \\
\hline Ort \pm SS & \multicolumn{2}{|c|}{$3.9 \pm 5.9$} & \multicolumn{2}{|c|}{$2.1 \pm 4.2$} & $12.982 ; 0.012 *$ \\
\hline
\end{tabular}

Öğrencilerin (1. ve 4 sınıf) \%61.2'sinin ileriye yönelik yalnızca hemşirelik eğitimini bitirmeyi planladıkları her iki sınıf arasında anlamlı fark olmadığı belirlendi ( $p>0.05)$. Buna rağmen öğrencilerin \%37.3'ünün başka bir bölümde lisans eğitimi almayı planladıkları ya da eş zamanlı olarak başka bir bölümde eğitim aldığı belirlendi. Öğrencilerin \%10'unun ise halen açık öğretim fakültesinde farklı bir bölümde eş zamanlı olarak öğrenimine devam ettikleri ve bu öğrencilerin \% 77.3'ünün istatistiksel olarak anlamlı farkla dördüncü sınıfta öğrenim gören öğrenciler oldukları belirlen$\operatorname{di}(\mathrm{p}<0.05)$.

Birinci ve 4. sınıf öğrencilerine "Öğreniminizi tamamladığınızda mesleki olarak gelecek planladığ1nız nedir?” sorusu sorulduğunda; öğrencilerin büyük çoğunluğunun (\%63.4) "Hemşirelikte ilerlemek ve yüksek lisans yapmak istiyorum" cevabını verdiği ve sınıflara göre öğrencilerin lisansüstü eğitim yapmayı isteme durumu arasında anlamlı fark olmadı̆̆ 1 (birinci sınıf \%54.7; dördüncü sinıf \%45.3; p>0.05) belirlendi. Öğrencilerin \%10.5'inin koruyucu sağlık hizmetlerinde çalışmak istedikleri görüldü. Dördüncü sınıf öğrencilerinin (\%83.3) koruyucu sağlık hizmetlerini birinci sınıflara göre daha fazla tercih ettiği saptand1. Ayrıca öğrencilerin \%15.7'sinin eğitimci olmak istediği ve eğitimci olmak isteyenlerin ise \%88.2'sinin 4. sınıf öğrencisi olduğu belirlendi. "Koruyucu sağlık hizmetlerinde çalışma" ve "eğitimci olma" bulgularının dördüncü sınıf öğrencilerinin lehine istatistiksel olarak anlamlı düzeyde farklı olduğu belirlendi $(\mathrm{p}<0.05)$.

Öğrencilere; “Öğreniminizi tamamladıktan sonra nerede yaşamayı planlıyorsunuz?” sorusu sorulduğunda ise 1. ve 4. sınıf öğrencilerinin yarısından fazlasının (\%55.3) İstanbul'da yaşamak istiyorum cevabını verdikleri görüldü. Ancak öğrencilerin gelecekte yaşamak istedikleri yere ilişkin verilerde sınıflar arasında istatistiksel olarak anlamlı bir fark olmadığı belirlendi ( $>00.05$ ). Öğrencilerin İstanbul'da yaşamak isteme nedenlerine bakıldığında ise 1 .sınıf öğrencilerin en çok "İstanbul geldiğim şehirden daha sosyalleşme olanağ sunuyor" ifadesini belirttikleri (\%49.7) ve 4. sinıfların 
Tablo 3. Hemşirelik Öğrencilerinin Kariyer Planları (N=217)

\begin{tabular}{|c|c|c|c|c|c|c|c|}
\hline Kariyere ilişkin özellikler & \multicolumn{2}{|c|}{$\begin{array}{l}\text { 1.sinif } \\
\text { n } \%\end{array}$} & \multicolumn{2}{|c|}{$\begin{array}{l}\text { 4.sinıf } \\
\text { n \% }\end{array}$} & \multicolumn{2}{|c|}{$\begin{array}{c}\text { Toplam } \\
\mathrm{N} * * * \%\end{array}$} & $\mathbf{X}^{2} ; \mathbf{p}$ \\
\hline \multicolumn{8}{|l|}{ Eğitim durumuna yönelik planlar } \\
\hline Başka bir bölüm için hazırlanıyorum/ okuyorum & 40 & 49.4 & 41 & 50.6 & 81 & 37.3 & $0.060 ; 0.806$ \\
\hline Bu bölümle birlikte açık öğretimde okuyorum & 5 & 22.7 & 17 & 77.3 & 22 & 10 & $\begin{array}{l}7.538 ; \\
0.006 *\end{array}$ \\
\hline Yalnızca kendi bölümümü bitirmeyi planlıyorum & 68 & 51.1 & 65 & 48.9 & 133 & 61.2 & $0.061 ; 0.805$ \\
\hline \multicolumn{8}{|l|}{ Mesleki kariyere yönelik planlar } \\
\hline Hemşirelikte yüksek lisans/ doktora yapmak & 75 & 54.7 & 62 & 45.3 & 137 & 63.4 & $2.747 ; 0.097$ \\
\hline Koruyucu sağlık hizmetlerinde çalışmak & 5 & 16.7 & 25 & 83.3 & 30 & 13.9 & $\begin{array}{l}15.918 \\
\mathbf{0 . 0 0 1} * *\end{array}$ \\
\hline Tedavi edici sağlık hizmetlerinde çalışmak & 19 & 40.4 & 28 & 59.6 & 47 & 21.8 & $2.421 ; 0.120$ \\
\hline Eğitimci olmak & 4 & 11.8 & 30 & 88.2 & 34 & 15.7 & $\begin{array}{l}24.174 \\
\mathbf{0 . 0 0 1} * *\end{array}$ \\
\hline $\begin{array}{l}\text { Özel sektörde hemşirelik dışı çalışmak (İlaç/ sigorta } \\
\text { firmaları) }\end{array}$ & 11 & 42.3 & 15 & 57.7 & 26 & 12 & $0.786 ; 0.375$ \\
\hline Yurtdışında hemşirelik yapmak & 10 & 50 & 10 & 50 & 20 & 9.3 & $0.002 ; 0.965$ \\
\hline \multicolumn{8}{|l|}{ Öğrencilerin yaşamak istedikleri yere ilişkin düşünceleri } \\
\hline Ailemin yanına dönmek istiyorum & 24 & 45.3 & 29 & 54.7 & 53 & 24.4 & $0.687 ; 0.407$ \\
\hline İstanbul'da yaşamak istiyorum & 64 & 53.3 & 56 & 46.7 & 120 & 55.3 & $1.034 ; 0.309$ \\
\hline Başka şehirde yaşamak istiyorum & 18 & 43.9 & 23 & 56.1 & 41 & 18.9 & $0.810 ; 0.368$ \\
\hline Başka bir ülkede yaşamak istiyorum & 6 & 46.2 & 7 & 53.8 & 13 & 6 & $1.117 ; 0.572$ \\
\hline \multicolumn{8}{|l|}{ Öğrencilerin İstanbul'da yaşamak isteme nedenleri } \\
\hline İstanbul'da geldiğim şehirden daha çok iş imkânı var & 84 & 47.5 & 93 & 52.5 & 177 & 87.2 & $\begin{array}{l}8.488 \\
\mathbf{0 . 0 3 7 *}\end{array}$ \\
\hline İstanbul'da çalışma ücretleri daha yüksek & 54 & 41.9 & 75 & 58.1 & 129 & 61.4 & $\begin{array}{l}7.404 ; \\
\mathbf{0 . 0 2 5 *}\end{array}$ \\
\hline İstanbul geldiğim şehirden daha sosyal & 91 & 49.7 & 92 & 50.3 & 183 & 88.8 & $\begin{array}{l}1.995 \\
0.369\end{array}$ \\
\hline İstanbul geldiğim şehirden daha fazla eğitim olanağı var & 87 & 48.9 & 91 & 51.1 & 178 & 86.4 & $\begin{array}{l}0.220 \\
0.896\end{array}$ \\
\hline
\end{tabular}

${ }^{*} \mathrm{p}<0.05$ olarak kabul edilmiştir. ${ }^{* *} \mathrm{p}<0.001$ olarak kabul edilmiştir, $* * *$ Birden fazla cevap verilmiştir

ise en çok "İstanbul' da geldiğim şehirden daha çok iş imkânı var" şeklinde ifade ettikleri (\%52.5) belirlendi (Tablo 3). İstanbul'un geldiği şehirden daha çok iş imkânı sunması nedeniyle İstanbul'da yaşamak isteyen öğrencilerin sayısı 4. sinıflar lehine istatistiksel olarak anlamlı bulundu ( $p>0.05$ ). Ayrıca İstanbul'da çalışma ücretlerinin daha yüksek olması nedeniyle İstanbul'da yaşamak isteyen öğrencilerin sayısı da 4. sinıflar lehine istatistiksel olarak anlamlı bulundu $(\mathrm{p}>0.05)$.

\section{TARTIŞMA}

Hemşirelik öğrencilerinin meslek seçiminde; insanlara yardımcı olma, işe ilgi duyma, insanlarla yakın ilişki içinde çalışma, iş güvencesi, seyahat imkanları, esnek çalışma saatleri, iş ortamından memnun olma, heyecan verici bir iş olması ve maaş gibi faktörler etkili olmaktadır (McCabe, Nowak ve Mullen 2005). Bunun yanında bireylerin çoğunlukla bir mesleğe ilgi duymaları nedeniyle değil, genellikle bazı kişi- 
sel, sosyal ya da ekonomik nedenlerle de seçebildiği belirtilmektedir (Rawlins, Riordan, Delamaide ve Kilian 1991). Çalışmamızda birinci sınıf öğrencilerinin yarıdan fazlasının ve dördüncü sınıf öğrencilerinin ise yarıya yakınının hemşirelik mesleğini bilinçli olarak seçtiği görülmüştür. Günümüzde öğrencilerin üniversiteye girişleri, genellikle üniversite giriş sınav1 ile yeteneklerin dışında veya rastlantısal olmasına rağmen çalışmamızda öğrencilerin bilinçli ve istekli olarak tercih yapmaları, hemşireliğe ilişkin algıda bir farklılaşma olduğunu düşündürebilir. Ülkemizde 116 hemşirelik öğrencisi ile yapılan benzer bir çalışmada öğrencilerin seçiminde genellikle üniversite giriş sınavında aldığı puan, boşta kalmamak ya da ailesinin isteğinin rol oynadığı görülmüştür (Dinç, Kaya ve Şimşek 2007). Çıtak-Tunç ve ark. (2010)'nın hemşirelik öğrencilerinin meslek seçimini etkileyen temel faktörleri araştırdıkları çalışmalarında; öğrencilerin üniversite tercih sıralamasında hemşirelik bölümünü ilk 10 tercih içinde yazdıkları belirtilmiştir. Yine aynı çalışmada öğrencilerin hemşireliği seçmeden önce bölüm hakkında bilgi aldıkları ve bilinçli tercih yaptıkları görülmektedir (Çıtak-Tunç ve ark. 2010). Dinç ve ark. (2007)'nın yaptığı çalışmada ise öğrencilerin hemşirelik mesleğini ilk sırada tercih etmeleri sınıflara göre incelendiğinde; birinci sınıfların \%41.5'inin ikinci, üçüncü ve dördüncü sınıfların sırasıyla \%22.6; \%20.8; \%15.1'inin tercih ettiği bildirilmiştir. Öğrencilerin hemşirelik eğitimine ve kariyerlerine ilişkin beklentileri hemşireliği seçmedeki motivasyonlarına ve hemşireliği bir kariyer ya da iş olarak algılamalarına göre değişiklik göstermektedir (Vanhanen ve Janhonen 2000). Çalışmamızda öğrencilere eğitimlerine yönelik planları sorulduğunda hem birinci hem de dördüncü sınıf öğrencilerin büyük çoğunluğunun sadece bölümü bitirmeye odaklandığ1 görüldü. $\mathrm{Bu}-$ nun nedeninin genellikle hemşire öğrencilerin gelecek planlarına karar vermelerinin mezuniyetten 2-5 y1l sonra şekillenmesi ve bu sürede kariyer hedeflerini değerlendirmeleri ve yol göstericiler aramaları ile ilgili olduğu düşünülmektedir (Donner ve Wheeler 2001). Bununla birlikte çalışmamızda birinci s1nıf öğrencilerin büyük çoğunluğunun henüz mezun olmadan hemşirelikte ilerlemek ve yüksek lisans yapmak istedikleri belirlendi Ayrıca, öğrencilerin mezuniyet sonrası eğitimci/ akademisyen olmak istedikleri saptandı. Sonuç olarak gelecek planlarına ilişkin düşüncelerinin lisans eğitimi sırasında şekillenmeye başladığı görüldü. Literatüre bakıldığında Dinç ve ark. (2007)'nın yapmış olduğu çalışmada hemşirelik öğrencilerinin \%44.8'inin hemşirelikte lisansüstü eğitim yapmak ve akademisyen olmak istediği belirlenmiştir. Dereli ve Demir (1997)'in yaptıkları çalışmada öğrencilerin \%28.8'i mezun olduktan sonra yönetici olarak görev almak isterken, \%23.2'si hemşirelik yüksekokullarında araştırma görevlisi olarak, \%16's1 klinik hemşiresi olarak görev almak istediklerini ifade etmişlerdir. Yapılan çalışmalarda öğrencilerin kliniklerde çalışmaktan çok lisansüstü eğitim almak ve kariyer planlarını akademisyenliğe yönelik yapmakta oldukları görülmektedir (Dereli ve Demir 1997; Dinç ve ark. 2007). Bu durumun kliniklerdeki yetersiz çalışma koşullarından, fazla mesai saatleri ve iş yükünden kaynaklandığı, genel olarak meslekte yaşanan sorunların büyük ölçüde akademisyenliğe veya yönetici hemşireliği seçmeye yönelttiği şeklinde yorumlanabilir. Öğrencilerin hemşirelik eğitimi alırken daha mesleğin gerçek istihdam alanından kaçış için çözüm olarak akademisyenliği kariyer planlaması kapsamına alması, iki yönlü olarak olumsuz değerlendirilebilir. Hemşirelik eğitimi, çalışma hayatı sorunları ve çözüm önerilerine yönelik hala daha fazla çalışmaya ihtiyaç vardır.

Bütün Dünya'da 1970'li yıllardan itibaren koruyucu sağlık hizmetleri, tedavi merkezli bakım hizmetlerinden daha çok ön plana çıkmıştır (Dinç ve ark. 2007). Bu durum, hemşirelik eğitiminde de önemli yansımalara neden olmuştur. Çalışmamızda koruyucu sağlik hizmetlerinde çalışmak isteyen öğrencilerin çoğunluğunun 4. sınıf öğrencilerinden oluşması düşündürücüdür. Her ne kadar bu bulgumuz tüm evreni temsil etmese de 4. sınıf öğrencilerinin mezuniyet sonrasındaki kariyer hedeflerine ilişkin bir fikir oluşturmaktadır. Yabancı literatüre baktığımızda; öğrenci hemşirelerle yapılan bir çalışmada da benzer şekilde öğrencilerin 
\%82'si hemşirelik alanında özellikle kadın doğum ve toplum sağlı̆̆ hemşireliği alanında özelleşmek istediklerini belirtmişlerdir (Rognstad 2002). Bunun nedeni öğrencilerin hastanede çalışma koşullarının zorluğundan dolayı, hasta bireyle çalışmak yerine bireylerin sağlı̆̆ını koruma ve yükseltmeye yönelik koruyucu sağlık hizmetlerinde çalışmayı tercih etmesinden kaynaklanabilir. Öğrencilerin ve çalışan hemşirelerin çalışma alanlarını seçme tercihlerinde etkili olan faktörlerin irdelendiği çalışmalar ile ülkemizde durumun açıklanması önerilebilir.

Öğrencilere, eğitimlerini bitirdikten sonra yaşamak istedikleri yerler sorulduğunda; birinci sınıf öğrencilerin yarısından fazlasının (\%53.3) ve 4. sınıf öğrencilerinin yarıya yakınının (\%46.7) İstanbul'da yaşamak istedikleri belirlendi. Öğrencilerin ailelerinin bu bölgede yaşamasının İstanbul'da kalmak için önemli bir gerekçe olabileceği gibi; çalışmamızda öğrencilerin çoğunlukla İstanbul'da iş bulma, eğitim alma ve sosyal olma olanağı olması nedeniyle de bu bölgede yaşamak istedikleri görülmektedir. Avusturalya' da gerçekleştirilen bir çalışmada da benzer şekilde hemşirelik eğitimi alan son sınıf öğrencilerinin büyük hastanelerde çalışmak istedikleri ve çalışırken aynı zamanda lisansüstü eğitimlerine de devam etmek istedikleri belirtilmiştir (Heslop, McIntyre ve Ives 2001). Bu öğrencilerin aynı zamanda son sinıfa geldiklerinde kendilerini kariyer anlamında geliştirme ihtiyacı içerisinde olduklarını göstermesinden dolayı önemli bir bulgu olarak görülmektedir.

\section{SONUÇ VE ÖNERILLER}

Birinci sınıf öğrencilerin dördüncü sınıf öğrencilere göre daha bilinçli bir şekilde hemşirelik mesleğini tercih ettikleri görülmüştür. Öğrencilerimizin çoğunluğu ise ileriye yönelik sadece hemşirelik eğitimlerini bitirmeyi planladıkları ve aynı zamanda büyük çoğunluğunun öğrenimini tamamladığında hemşirelikte ilerlemek ve yüksek lisans yapmak istedikleri belirlenmiştir. Dördüncü sınıf öğrencileri çoğunlukla koruyucu sağlık hizmetlerinde çalışmak istemektedir.
Çalışmamızda öğrencilerimizin yarısından fazlasının eğitimlerini tamamladıktan sonra kariyerlerine İstanbul'da devam etmek istedikleri ve bunun primer nedenlerinin de her iki sınıf için özellikle İstanbul'da çalışma olanaklarının ve sosyal olanakların daha fazla olması olarak belirlenmiştir.

Hemşireliğin algılanışı ve bilinçli seçilmesi özellikle de gelecek dönemde hemşirelik mesleğinin gelişimine önemli katkılar sağlayabilecektir. Bu süreçte hemşire eğitimciler; toplum değerlerine, öğrencilerin ilgilerine ve hedeflerine uygun eğitim, klinik deneyim-beceri geliştirme ve gelecekte kariyer firsatlarına ulaşabilmelerinde en önemli rehberlerdir. Eğitim sürecinin olumlu geçmesi hemşire öğrencilerin gelecekteki mesleki yaşantılarına daha iyi uyum sağlamalarına, bilinçli ve istekli bir şekilde ilerledikleri mesleklerinden doyum almalarına büyük katkı sağlayacaktır. Bunun sonucunda hasta bakım kalitesi artabilir ve hemşire-hasta arasında karşılıklı memnuniyet sağlanabilir. Bu nedenle eğitimciler, işverenler ve mesleki örgütler, hemşirelik alanında kariyer planlama konusunda öncelikle öğrencilik döneminde olmak üzere, mezuniyet sonrasında da kliniklerde çalışan hemşirelere ilgi duydukları alanlarda kendilerini geliştirebilmeleri için desteklemelidirler.

Birinci sınıftan itibaren öğrencilere Türkiye'nin her bölgesinde ve farklı hemşirelik alanlarındaki çalışma olanakları hakkında bilgi verilmesi sonucunda geleceğin hemşirelerinin daha bilinçli mesleki tercihler yapacakları ve böylece hemşirelik hizmetlerindeki bölgelere göre dağılımın da dolaylı olarak daha eşit düzeye geleceği düşünülmektedir. Bunun yanında mesleki yaşamın, klinik ve profesyonel uygulamaların vazgeçilmez bir parçası olan sürekli eğitim programlarının parçası olan kariyer planlama konularını da içermesi gerekmektedir.

Müfredatta kariyer planlamaya yönelik derslerin olması, öğrencilerin alanda çalışan hemşirelerle sürekli iletişimde olması ve onların deneyimlerinden yararlanmaları öğrencilerin kariyer planlarına yön verecektir. Konu ile ilgili daha fazla sayıda öğrenci ile araştırma yapılması önerilmektedir. 


\section{KAYNAKLAR}

Andrew, N. (2013). Clinical imprinting: The impact of early clinical learning on career long professional development in nursing. Nurse Education Practice, 13(3): 161-164.

Çıtak-Tunç, G., Akansel, N., Özdemir, A. (2010). Hemşirelik ve sağl1k memurluğu öğrencilerinin meslek seçimlerini etkileyen faktörler. Maltepe Üniversitesi Hemşirelik Bilim ve Sanatı Dergisi, 3(1): 24-31.

Dereli, N., Demir, Ü. (1997). Hemşirelik yüksekokulu birinci s1nıf öğrencilerinin meslek bilinçlerinin incelenmesi. Uluslararası Katılımlı IV. Ulusal Hemşirelik Eğitimi Sempozyumu Kitabı, Çevik Matbaacilık, İstanbul, 182-187.

Dikili, A. (2012). Yeni kariyer yaklaşımlarına ilişkin değerlendirmeler. Süleyman Demirel Üniversitesi İktisadi ve İdari Bilimler Fakültesi Dergisi, 17(2): 473-484.

Dinç, S., Kaya, Ö., Şimşek, Z. (2007). Harran Üniversitesi Sağlık Yüksekokulu öğrencilerinin hemşirelik mesleği hakkındaki bilgi, düşünce ve beklentileri. Atatürk Üniversitesi Hemşirelik Yüksekokulu Dergisi, 10(1): 1-9.

Donner, G. J., Wheeler, M. M. (2001). Career planning and development for nurses: The time has come. International Nursing Review, 48(2): 79-85.

Edwards, H., Smith, S., Courtney, M., Finlayson, K., Chapman, H. (2004). The impact of clinical placement location on nursing students' competence and preparedness for practice. Nurse Education Today, 24(4): 248-255.

Fenush, J. K., Hupcey, J. E. (2008). An investigation of clinical unit choices by graduating baccalaureate nursing students. Journal of Professional Nursing, 24(2): 90-95.

Göz, F., Gürbüz, K. (2008). Hemşirelikte kariyerinizi keşfedin. Atatürk Üniv. Hemşirelik Yüksekokulu Dergisi, 8(2): 82-87.

Henderson, A., Cooke, M., Creedy, D. K., Walker, R. (2012). Nursing students' perceptions of learning in practice environments: A review. Nurse Education Today, 32(3): 299-302.

Heslop, L., McIntyre, M., Ives, G. (2001). Undergraduate student nurses' expectations and their self-reported preparedness for the graduate year role. Journal of Advanced Nursing, 36(5): 626-634.

International Council of Nurses (ICN) (1995). Career Development for Nurses: Working Document, Geneva.
Lai, H. L. ve ark. (2008). Is nursing profession my first choice? A follow up survey in pre-registration student nurses. Nurse Education Today, 28(6): 768-776.

McCabe, R., Nowak, M., Mullen, S. (2005). Nursing careers: What motivated nurses to choose their profession? Australian Bulletin of Labour, 31(4): 384-406.

McKenna, L., McCall, L., Wray, N. (2010). Clinical placements and nursing students' career planning: A qualitative exploration. International Journal of Nursing Practice, 16(2): 176-182.

Morrell, N., Ridgway, V. (2014). Are we preparing student nurses for final practiceplacement? British Journal of Nursing, 23(10): 518-523.

Neilson, G. R., McNally, J. G. (2010). Not choosing nursing: Work experience and career choice of high academic achieving school leavers. Nurse Education Today, 30(1): 9-14.

Rawlins, T., Riordan, J., Delamaide, G., Kilian, G. (1991). Student nurse recruitment: Determinants for choosing a nursing program. Journal of Nursing Education, 30(5): 197-201.

Rognstad, M. K. (2002). Recruitment to and motivation for nursing education and the nursing profession. Journal of Nursing Education, 41(7): 321-325.

Rognstad, M. K., Aasland, O., Granum, V. (2004). How do nursing students regard their future career? Career preferences in the postmodern society. Nurse Education Today, 24(7): 493-500.

Shih, W. M., Chuang, S. H. (2008). Factors influencing student nurses' career choices after preceptorship in a five-year junior nursing college in Taiwan. Nurse Education Today, 28(4): 494-500.

Shoqirat, N., Abu-Qamar, M. Z. (2015). From placement to employment: Career preferences of Jordanian nursing students. Nurse Education in Practice, 15(5): 366-372.

Vanhanen, L., Janhonen, S. (2000). Factors associated with students' orientations to nursing. Journal of Advanced Nursing, 31(5): 10541062.

Yıldırım, D., Kececi, A., Bulduk, A. (2011). How do Turkish nursing students plan their career after the graduation? A questionnaire survey. Asia Pacific Education Review, 12(3): 373-380.

Yıldırım, T. (2009). Sağlık çalışanları ve uluslararası göç: Göç nedenleri üzerine bir inceleme. Ankara Üniversitesi Tip Fakültesi Mecmuasl, 62(3): 87-94. 